\title{
USE OF GROUND-LEVEL OR ELEVATED BAIT STATIONS FOR POSSUM CONTROL
}

\author{
R.J. HENDERSON ${ }^{1 *}$, J.A. BROWN ${ }^{2}$, M.D. THOMAS ${ }^{1 *}$ \\ and R.J. McAULIFFE ${ }^{3}$
}

\author{
${ }^{1}$ Landcare Research, PO Box 69, Lincoln, New Zealand \\ ${ }^{2}$ Biomathematics Research Centre, Dept. of Mathematics and Statistics, \\ University of Canterbury, Private Bag 4800, Christchurch \\ ${ }^{3}$ Ecology and Entomology Group, Lincoln University, PO Box 84, Lincoln \\ *Present Address: Pest Solutions, PO Box 31191, Christchurch
}

\begin{abstract}
Bait stations were located near ground-level or elevated $1.5-2 \mathrm{~m}$ above the ground, and the amounts of bait eaten from them by captive and wild possums (Trichosurus vulpecula) were measured. The percentage of possums killed by ground level or elevated bait stations containing cholecalciferol or 1080 baits was also monitored. The per capita amounts of bait eaten by captive possums was significantly higher at ground level than at elevated bait stations. Wild possums also ate more bait from ground-level than elevated bait stations, but this difference was mainly attributed to fewer possums finding elevated bait stations. There was no difference in the kills achieved with baits containing cholecalciferol and 1080 . However, the kills at ground-level stations $(84 \%, \mathrm{n}=9)$ were higher than at elevated stations $(52 \%, \mathrm{n}=10)$. Because pest controllers routinely place bait stations up trees out of reach of domestic livestock and ground-birds, the implications of prefeeding elevated bait stations to improve the percentage of possums killed should be evaluated.
\end{abstract}

Keywords: possum, baits, pest control, bait stations.

\section{INTRODUCTION}

Possums (Trichosurus vulpecula) are considered New Zealand's most serious vertebrate pest (King 1990). They reduce forestry and agricultural production, damage indigenous forests, and prey on invertebrates, small animals, birds and eggs (Cowan 1991; Cowan and Moeed 1987; Brown et al. 1993). In 1967 possums were found to be infected with bovine tuberculosis (Mycobacterium bovis) (Lever 1985), and in the early 1970 s control began along forest margins and on farmland to prevent the spread of $\mathrm{Tb}$ to cattle (Atkinson et al. 1995).

During the past decade, control of possums has often been undertaken by ground based hunters applying toxic baits in bait stations (Thomas 1994). This technique has several advantages over other methods of possum control. For example, following such operations, toxic baits not eaten by possums can be removed from the control area, enabling farmland to be restocked more quickly than when baits are aerially broadcast. Bait station control is also likely to be less hazardous to non-target species, because bait is partially enclosed in a container, and because there is less toxic bait in the environment (Thomas et al. 1996). To further reduce the risks to non-target species, bait stations are often raised $2 \mathrm{~m}$ above ground level, out of reach of domestic livestock (e.g., cattle, sheep, deer) and ground birds (e.g., kiwi, weka). However, it is not known whether elevated bait stations are as effective for the control of possums as bait stations located near ground level.

This study compared the amounts of bait eaten from bait stations that were raised $1.5-2 \mathrm{~m}$ above ground with those located $25 \mathrm{~cm}$ above ground, and the frequency at

Proc. 52nd N.Z. Plant Protection Conf. 1999: 130-135 
which such bait stations were used by captive and wild possums. We then compared the percentages of possums killed by elevated and ground-level bait stations in replicated field trials.

\section{MATERIALS AND METHODS \\ Bait consumption from elevated and ground level bait stations a) Pen studies}

A 'Control' bait station (M.D. Thomas, Christchurch) mounted on electronic scales (Sartorius QS scales, Goettingen, Germany) was located either on the ground or on a platform elevated $1.5 \mathrm{~m}$ above ground in each of four wire mesh enclosures (measuring $4 \mathrm{~m} \mathrm{x} 4 \mathrm{~m}$ ). Each enclosure housed one possum. The bait stations were filled with $1.2 \mathrm{~kg}$ of non-toxic RS5 cereal bait (Animal Control Products, Waimate) and the amounts of bait eaten throughout the night were monitored using a Psion 'workabout' datalogger (Pocket Solutions, Wellington). This recorded the weight of bait remaining and weight of the feeding possum at 10-sec intervals (when it was present). The amount of bait eaten during each feeding bout was calculated from the weight of bait present before and after the possum was recorded on the scales. The amounts of bait eaten were recorded for 79 different possums on their first night of exposure to bait. On the night possums were exposed to the bait, they were also offered alternative foods (i.e., apples, carrots, and a mix of green vegetables).

Comparisons of the amounts of non-toxic RS5 bait eaten from elevated and ground-level bait stations was limited to the first hour that possums fed on baits. This is because after possums have fed on baits containing a standard concentration of 1080 (i.e., $0.15 \%$ ) and eaten a lethal dose (i.e., $>4 \mathrm{mg} / \mathrm{kg}$ of 1080), 1080 toxicosis causes them to lose their appetite within 60 min of first eating bait (Henderson et al. 1999). The amounts eaten during this first hour of feeding were log-transformed, then compared by ANOVA using bait station placement as a treatment factor.

\section{b) Field studies}

'Sentry' bait stations (Pest Management Services, Waikanae) were sited at 12- m intervals on three parallel transects within a 90-ha block of indigenous forest on Banks Peninsula in Canterbury. Alternate bait stations were nailed to trees $25 \mathrm{~cm}$ above ground $(n=30)$ or $1.5-2 \mathrm{~m}$ above ground $(n=30)$. The bait stations were filled with 200 $\mathrm{g}$ of toxic RS5 bait containing $0.15 \% 1080$. At weekly intervals portable electronic scales were used to weigh the bait remaining in each bait station. The weight of bait remaining in bait stations was corrected for weight changes (hydration or dehydration) resulting from variations in temperature and humidity, by measuring the average weight loss or weight gain in bait in 15 'control' stations from which possums were excluded. The corrected weight of bait remaining was deducted from the amount present at the start of each week to estimate weekly bait consumption.

All bait consumption data were transformed to normality using the natural log scale before being analysed. The weekly bait consumption from elevated and ground level bait stations was compared using unpaired t-tests. Fisher Exact tests were used to compare the proportion of elevated and bait stations near ground level at which feeding occurred each week.

\section{Efficacy of elevated and ground level bait stations}

Replicated field trials were carried out by Landcare Research, Wellington Regional Council, and Taranaki Regional Council to test the efficacy of cholecalciferol and 1080 baits. These baits were trialled in bait stations placed $25 \mathrm{~cm}$ above ground level or up trees out of reach of most livestock (i.e., $>1.5 \mathrm{~m}$ above ground level). The field sites chosen were either discrete plantations of exotic forest or patches of indigenous forest that ranged from 18 to 50 ha. Before the application of toxic bait, the approximate abundance of possums at each site was estimated using 100 Victor leghold traps that allowed possums to be caught and released with minimal injury. If more than $20 \%$ of the traps set for 2 nights caught possums, then the site was considered to contain an adequate density of possums to undertake a field trial. Bait stations were distributed at a density of $1 / \mathrm{ha}$. They were located mainly around the edge of each forest block at approximately $100 \mathrm{~m}$ spacing, although some were also sited within the 
blocks of forest to ensure bait was readily accessible to all possums. At each site, bait stations were either located at the base of trees so that they were accessible to possums standing on the forest floor, or located up trees $>1.5 \mathrm{~m}$ above ground. Bait stations at each site were either filled with $200 \mathrm{~g}$ of bait containing $0.8 \%$ cholecalciferol or 200 $\mathrm{g}$ of bait containing $0.15 \% 1080$ (the concentrations of toxins in bait were confirmed by standard laboratory analyses before each field trial). Baits were left in the field for 35 days, by which time almost all possums would have fed on bait and negligible further amounts of bait would be eaten (Henderson et al. 1994). At the completion of each field trial, the leg-hold traps were reset and used for assessment of animal abundance after poisoning. The percentage of the population killed was estimated from the percentage decline in the proportion of traps that caught possums after poisoning, relative to the proportion of traps that caught possums before poisoning.

For all field trials, the percentage of possums killed by cholecalciferol and 1080 baits, and the percentage kills with elevated and ground-level bait stations were compared by two-way ANOVA.

\section{RESULTS \\ Bait consumption from elevated and ground level bait stations \\ a) Pen studies}

The amounts of RS5 bait eaten by captive possums during the first 60 min feeding was dependent on whether the bait stations were located near ground level (35 g/ possum) or $1.5 \mathrm{~m}$ above the ground $(22 \mathrm{~g} /$ possum $)\left(\mathrm{F}_{1,65}=7.16, \mathrm{P}=0.009\right)$. Fewer possums ate amounts of bait that were potentially sub-lethal (i.e., $<6 \mathrm{~g}$ ) at bait stations near ground-level ( $4 \%$ or $2 / 47$ possums) than at elevated bait stations $(22 \%$ or $7 / 32$ possums).

\section{b) Field studies}

Significantly more bait was eaten by wild possums from bait stations near ground - level than from bait stations $1.5-2 \mathrm{~m}$ above ground for all 5 weeks ( $\mathrm{P}$ values $<0.05$ ) (Fig. 1). The amounts of bait eaten declined after the first week as individuals in the target population died. Throughout the field trial possums fed from fewer bait stations up trees than bait stations near ground-level (Fig. 2). However, because of small sample sizes, the usage of elevated and ground level bait stations were only significantly different in weeks 1 and 4 (Fig. 2).

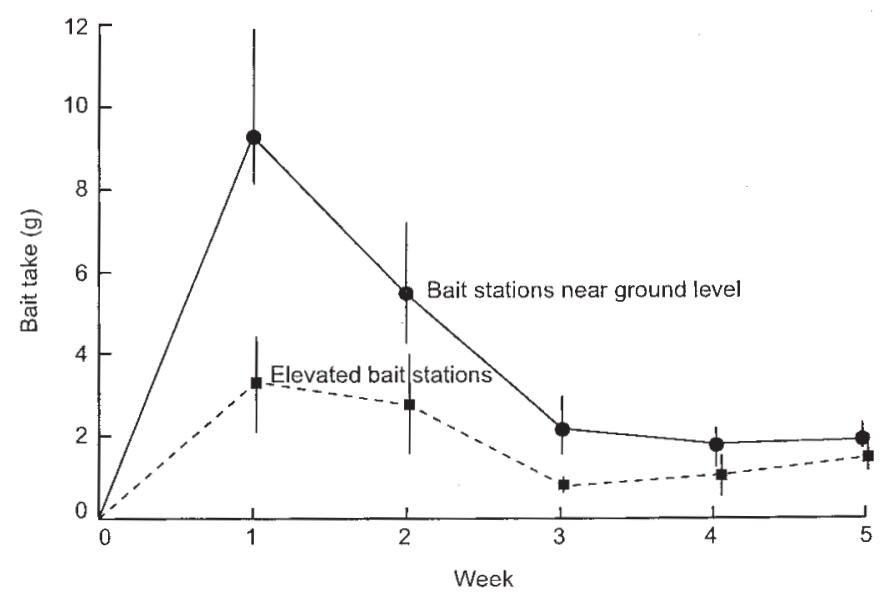

FIGURE 1: Mean weekly amounts of bait eaten ( \pm S.E. $)$ by wild possums from bait stations placed $25 \mathrm{~cm}$ or $1.5-2 \mathrm{~m}$ above ground level. 


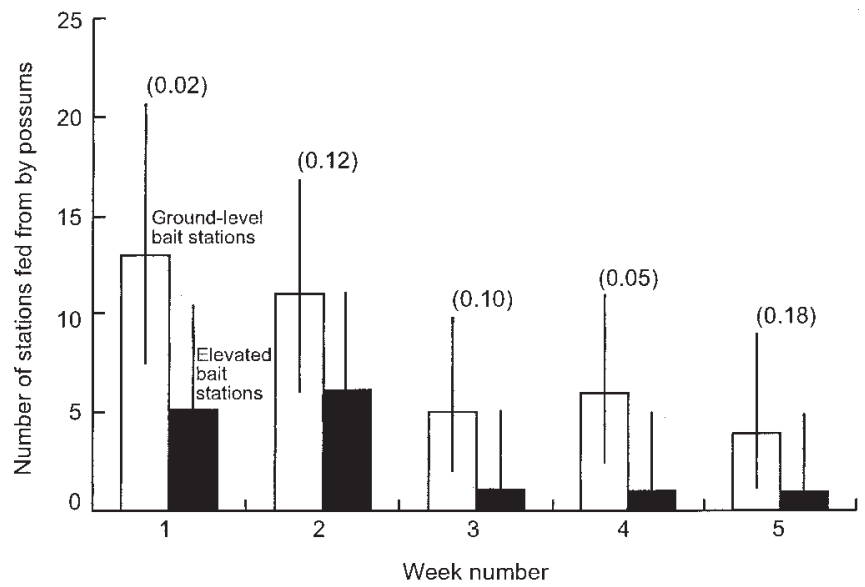

FIGURE 2: The number of high and low bait stations used per week by wild possums $( \pm 95 \%$ binomial confidence intervals $)$. Numbers in parentheses indicate statistical significance of differences using Fisher Exact tests $(\mathbf{P}<0.05)$.

\section{Efficacy of elevated or ground level bait stations}

In 19 replicated field trials, the percentage kills were significantly affected by the placement of bait stations $(\mathrm{F}=32.12$, d.f. $=1,15, \mathrm{P}<0.001)$. However, there was no difference in the mean kill achieved with recently manufactured RS5 baits that contained $0.8 \%$ cholecalciferol or $0.15 \% 1080(\mathrm{~F}=1.23$, d.f. $=1,15, \mathrm{P}=0.28)$, (Table 1$)$. Bait stations positioned near the ground consistently achieved higher kills than bait stations sited up trees out of reach of livestock (Table 1).

TABLE 1: Percentage kills achieved without pre-feed when bait stations containing cholecalciferol and 1080 baits were situated near groundlevel or sited up trees out of reach of livestock. The number of field trials is in parentheses.

Toxicant and concentration in RS5 bait
Placement of bait station and

percentage kill $( \pm 95 \%$ C.I. $)$

Near ground level $\quad 1.5-2 \mathrm{~m}$ above ground

\begin{tabular}{lll}
\hline Cholecalciferol $(0.8 \%)$ & $82.0 \pm 8.7(\mathrm{n}=5)$ & $46.8 \pm 25.1(\mathrm{n}=5)$ \\
$1080(0.15 \%)$ & $87.0 \pm 16.5(\mathrm{n}=4)$ & $56.6 \pm 14.9(\mathrm{n}=5)$ \\
\hline
\end{tabular}

\section{DISCUSSION}

In Australian forests, possums mainly feed in trees, and only $11-23 \%$ of feeding activity occurs at ground-level (Freeland and Winter 1975; MacLennan 1984). Although the relative amount of time possums spend feeding on the forest floor has not been evaluated in New Zealand, the median amounts of time that radio-tagged possums spent in terrestrial $(17 \%)$ and arboreal activity $(83 \%)$ was very different (Ward 1978). Because possums feed mainly up trees, it might therefore be expected that bait stations elevated up trees are likely to be used more than those located near the ground. However, individual possums apparently climb and feed from only a small percentage of the trees in their home range; typically they return to the same feed trees 
night after night (Meads 1976; Ward 1978; MacLennan 1984). For example, during a 2 -year period radio-tagged possums in a mixed podocarp forest were recorded in only $25 \%$ of the different species of trees, shrubs, and lianes present (Ward 1978).

In this study, wild possums used bait stations elevated up trees less frequently than bait stations located $25 \mathrm{~cm}$ above the ground. Fewer visits to elevated bait stations resulted in less bait being consumed from them than from ground-level bait stations. However, it is also possible wild possums ate smaller per capita amounts of bait from bait stations up trees. Bait presented to possums was eaten in smaller amounts from bait stations on elevated platforms than from bait stations located near the ground.

The percentage of possums killed during field trials was dependent on whether bait stations were placed up trees $(52 \%$ kill, $n=10)$ or located near the ground ( $84 \%$ kill, $\mathrm{n}=9$ ). These large differences suggests that in operations where pre-feed is not applied, operators should locate toxic baits in bait stations placed $25 \mathrm{~cm}$ above ground-level.

The use of pre-feed results in possums being attracted to bait stations when other animals are feeding at them (Thomas 1998). Pre-feeding is therefore likely to ensure most possums locate bait stations placed up trees. Pre-feeding also increases the per capita amounts of bait eaten (R. Henderson and C. Frampton unpubl. data). Further field trials should therefore be undertaken to establish whether pre-feeding at elevated bait stations before the application of toxic baits provides effective control of most possums.

\section{ACKNOWLEDGEMENTS}

We thank Lynne Milne and the staff of the Landcare Research animal facility for assistance with the penned studies. We also thank Grant Morriss and regional council staff for providing assistance with fieldwork. The Animal Health Board funded the research as part of a program aimed at reducing the proportion of possums that survive control operations. John Parkes, Jim Coleman and Dave Morgan provided helpful comments on drafts of the paper.

\section{REFERENCES}

Atkinson, I.A.E., Campbell, D.J., Fitzgerald, B.M., Flux, J.E.C. and Meads, M.J., 1995. Possums and possum control; effects on lowland forest ecosystems. Sci.for Conserv. No. 1, Dept. of Conserv., Wellington, N.Z. 32 p.

Brown, K., Innes, J. and Shorten, R., 1993. Evidence that possums prey on and scavenge birds' eggs, birds, and mammals. Notornis 40: 169-177.

Cowan, P.E., 1991. The ecological effects of possums on the New Zealand environment. Pp. 73-78. In: Vet. Cont. Educ. Publ. No. 132. Symposium on tuberculosis. Massey University, Palmerston North. 293 p.

Cowan, P.E. and Moeed, A., 1987. Invertebrates in the diet of brushtail possums from Kapiti Island, a New Zealand nature reserve. Biol. Cons. 61: 217-214.

Freeland, W.J. and Winter, J.W., 1975. Evolutionary consequences of eating: Trichosurus vulpecula and the genus Eucalyptus. J. Chem. Ecol. 1: 439-455.

Henderson, R.J., Frampton, C.M., Thomas, M.D. and Eason, C.T., 1994. Field evaluations of cholecalciferol, gliftor, and brodifacoum for the control of brushtail possums (Trichosurus vulpecula). Proc. $47^{\text {th }}$ N.Z. Plant Prot. Conf.: 112-116.

Henderson, R.J., Frampton, C.M., Morgan, D.R. and Hickling, G.J., 1999. The efficacy of baits containing sodium monofluoroacetate (1080) on captive brushtail possums (Trichosurus vulpecula). J. Wildl. Management (in press).

King, C.M., 1990. Introduction. Pp 3-21. In: The Handbook of New Zealand Mammals. C.M. King (Ed.). Oxford University Press, Auckland. 600p.

Lever, C., 1985. Naturalized Mammals of the World. Longman, London. 487 p.

MacLennan, D.G., 1984. The feeding behaviour and activity patterns of the brushtail possum in an open Eucalypt woodland in southeast Queensland. Pp. 155-161.In: Possums and Gliders. A.P. Smith and I.D. Hume (Eds.). Australian Mammal Society, Sydney.

Meads, M.J., 1976. Effects of possum browsing on northern rata trees in the Orongorongo Valley, Wellington. N.Z. J. Zool. 3: 127-139. 
Thomas, M.D., 1994. Possum control in native forests using sodium monofluoroacetate (1080) in bait stations. Proc. 47th N.Z. Plant Prot. Conf: 107-111.

Thomas, M.D., Henderson, R.J., Hickling, G.J., 1996. Optimising the use of bait stations for possum control. Pp. 65-69. In: Proceedings of a Workshop on Improving Conventional Control of Possums. Wright, D.E. (Ed). Royal Society of New Zealand Miscellaneous Series 33.

Thomas, M.D., 1998. Optimising the use of bait stations to control possums in New Zealand native forests. Proc. $11^{\text {th }}$ Aust. Vert. Pest Conf., Banbury, W.A: 337-340.

Ward, G.D., 1978. Habitat use and home-range of radio-tagged possums in New Zealand Lowland forest. Pp. 267-287. In: The Ecology of Arboreal Folivores. G.G. Montgomery (Ed.). Smithsonian Institution Press, Washington D.C. 